\title{
The Relevance of Small Parties: From a General Framework to the Czech "Opposition Agreement"*
}

\author{
MIROSLAV NOVÁK ${ }^{* *}$ \\ Faculty of Social Sciences, Charles University, Prague
}

\begin{abstract}
This paper has two primary aims. The first is to briefly outline the general question of the relevance of small parties. The second aim is in this context to characterise the interesting situation that has emerged in the Czech Republic since the early elections into Parliament were held in June 1998. Following the elections the two strongest parties (ČSSD and ODS) reached a written agreement with the purpose of limiting the influence of small parties as well as making it easier to form a government. A modification of the electoral system in the Chamber of Deputies, as well as a significant strengthening of these two large parties at the expense of the small ones, would bring about a situation not particularly harmful to Czech democracy and in fact, quite the opposite, would contribute to the consolidation of democracy.

Czech Sociological Review, 2000, Vol. 36 (No. 1: 27-47)
\end{abstract}

\section{Introduction}

The role of small parties has at present become a discussion topic of particular importance. In the Czech political scene, this fact stems from the emergence of what is known as the "agreement on creating a stable political environment" (often referred to as the "opposition agreement"), which was concluded by the Civic Democratic Party (ODS) of Václav Klaus, and the Social Democratic Party (ČSSD) of Miloš Zeman in July 1998. The two largest parties (ČSSD and ODS) appear to have reached an agreement aimed among other things at limiting the influence of small parties (especially KDU-ČSL and US). It seems as though the conflict here is set between the large parties on the one hand and the small parties on the other. In fact, the small and very small parties even united to form a type of four-party coalition (KDU-ČSL, US, ODA, DEU) in the November 1998 Senate by-elections in order to enable them to compete against the two largest parties.

In many western democracies, over the last three decades party fragmentation ${ }^{1}$ has been on the rise, which means that other parties have asserted themselves more perma-

*) Due to length restrictions the full text of this paper was shortened. The missing sections include: (a) The sociological and technical factors behind party fragmentation, (b) The classification of small parties, and (c) Electoral systems and small parties. Those interested in reading the full text should contact the author directly by email or mail.

**) Direct all correspondence to: Dr. Miroslav Novák, Associate Professor of Political Science, Institute of Political Studies, Faculty of Social Sciences, Charles University, Ovocný trh 3, CZ-116 36 Prague 1, Czech Republic, Office Fax: +42-2-26 09 21, e-mail: MNovákGE@hotmail.com, or Novak@mbox.fsv.cuni.cz

1) This clearly becomes evident in a simple indicator, which is the number of parties in Parliament. The information to be found in the fourth edition of this well-known work, written by J.-E. Lane and S. Ersson, speaks clearly. While the average number of parties represented in Parliament in eighteen Western European countries between 1950-1969 has remained with slight variations 
nently, such as the Green parties (in connection with the "silent revolution" [Inglehart 1977], and extreme right-wing populist parties (in the context of the "silent counterrevolution") [Ignazi 1992]. While as recently as the 1960s the party system appeared to be "frozen", since that time it seems to have been slowly "defrosting". Moreover, a number of regional and ethnic parties have started to attract significant attention in western democracies, and these are most often also small parties when considered from a statewide (federal) point of view. All this increases the interest of studying the role of small parties in contemporary democracies.

In this paper I will attempt to briefly outline the general issue concerning the relevance of small parties, and in this light try to characterise the situation that has existed in the Czech Republic since the early elections to the lower chamber of Parliament were held in 1998, following which the two largest parties (ČSSD and ODS) concluded a written agreement with the intention of limiting the influence of small parties and facilitating the formation of government majorities.

\section{Size, Relevance and the Number of Parties}

The size of a party is often regarded as synonymous with its strength. A large party is thus a strong party, and a small party is a weak one. But we know of course that small parties can in fact play a disproportionately great role. This brings us to the question of the "relevance" 2 of small parties. When and why are small parties relevant? According to G. Sartori [1976, see also Sartori 1994 and Ware 1996: 148-149], a relevant party is one that either has coalition potential, i.e. it is a party that must be taken into account when a majority government is to be formed, or one that has blackmail potential, i.e. its presence in the political arena considerably alters the nature of the political competition (the arena is transformed from being centripetal into being centrifugal). Coalition potential has more to do with small parties than large ones, while blackmail potential is rather more characteristic of the relatively large parties, which either lack coalition potential altogether or possess this potential to a slight degree only (this has been the case of the Italian Communists, particularly in the 1950s). However, blackmail potential may also be found among small anti-system parties given certain circumstances (particularly when difficulties arise in setting up a majority government).

around 6.1, in the period 1970-1974 the average increased to 7.4(!) and over the ensuing period continued to increase. With the exception of the period 1980-1984, when the average was 7.6, the average has continued to 8.0 and up to the highest average, traced in the last researched period, 1995-1997: 9.2! [Lane and Ersson 1999: 142].

2) Both (the smallness of the party and its relevance) must be distinguished from one another, and those parties that for some reason are not relevant (for example due to the existing electoral system) should not be excluded from the category of small parties. Similarly, relevant parties should not be excluded from being small parties. We cannot consider the German Liberals (FDP) as a "large" party because for many decades it has been a "relevant" party. The coalition potential of a party also absolutely cannot be used as a criterion for distinguishing between large and small parties, which is the approach considered by A. Laurent, who claims that from the viewpoint of ties maintained with other political formations, a party can be termed as small if it is unable prior to the elections to conclude election agreements with other partners [Laurent and Villalba 1997: 25]. Laurent moreover takes into consideration only pre-election alliances, which is too limiting for the criterion of coalition potential. She further correctly points to a situation in which a certain party itself refused to enter into an alliance, for a time true of the Greens. 
The collective work Small Parties in Western Europe [Müller-Rommel and Pridham 1991], and the more recent French publication Les petits partis [Laurent and Villalba 1997] are two international academic publications devoted especially to the issue of small parties and the role they play in political systems. In the English publication, P. Mair introduces a list of 157 parties in Western Europe that managed to gain between 1 and 15 percent of the popular vote in national elections between 1947 and 1987. Political scientists focusing on comparative studies worked together with specialists on individual countries in order to compile the collection of papers, in one of which Müller-Rommel distinguishes between four approaches for providing a possible framework for analysis:

1) A conceptional definitional approach, which addresses the question of defining what small parties are and how to classify them within the European party systems.

2) A numerical and party family approach, which focuses on election trends and the results of various "families" of small parties.

3) A diachronic approach, which analyses the developmental cycles of small parties, their formation, successes, and possible extinction.

4) A systemic approach, which looks into the role and performance of small parties in relation to the state, society, and other political parties within the same political system.

What follows is mainly founded on the conceptional definitional approach, but it also makes use of the systemic approach. In the context of the conceptional definitional approach, the question of the political "relevanace" of small parties is of particular importance.

Specialists are unable to agree on a single set of criteria for determining which parties can be considered as being "small". Mair [1991] examines small parties in Western Europe whose "smallness" is defined by a level of support below $15 \%$ of the popular vote. Blondel [1968, see also Blondel 1990] distinguishes further between small parties and very small parties, whereby in his terms small parties maintain around $10 \%$ of the vote. In addition to large and small parties, Mair also refers to ephemeral or micro-parties, which have only weak election results (approximately 1\%), and in the period his research was focusing on (1947-1987) are witnessed in only three cases. However, it is necessary to stress that not only small parties but also even very small parties can sometimes be relevant (for example in Israel).

S. Fisher [1974] concludes that a party can be defined as small when at elections it is usually unable to attain a higher position than that of third place. J. Charlot, the recently deceased French specialist on political parties, was of a similar opinion, writing that a party which is not situated among the top three should be considered to be a small party [Charlot 1974]. But criteria of this type cannot be applied in a general manner. In particular, such criteria need not necessarily be applicable to those situations that Blondel refers to as "pure" multipartism, in which there is no dominant party. For instance in Switzerland, for many years a configuration of four main parties has managed to co-exist on the federal level: three leading parties that are roughly equal in size (Radicals FDP/PRD, Socialists - SPS/PSS, and Christian Democrats - CVP/PDC), and a fourth largest party (SVP/UDC) that also cannot be considered as minor. ${ }^{3}$

3) Of course it is well-known that in 1999, during the parliamentary elections, the SVP/UDC, whose influential Zurich canton section led by the populist C. Blocher was often compared with 
M. Duverger [1981: 383] is probably correct in pointing out that the classification of parties according to their size is only a rough measure and only significant when the differences in size also express a difference in substance. The basic distinction between parties according to size is not, in the view of Duverger [1981: 384], between large and small parties, but rather between those parties with a majority vocation, and all the others: not only small, but also medium and even some large parties.

While all other kinds of parties defined according to size have a strong tendency toward demagogy and irresponsibility, a party with a majority vocation is almost necessarily realistic. Its programme must pass through a "reality check". Clearly marked out and limited reforms usually move to the forefront of the programme and are far more likely to be included in the programme than are revolutionary principles, which are difficult to realise. In short, the party with a majority vocation is entirely focused on realisable activity and possesses a well-developed sense for realistic politics.

The rest of the parties are aware that their programmes cannot be compared with what in reality they will actually do, because it is clear that they will never be in power alone. They will at best be forced to share power with their allies, at the very least in the form of parliamentary support. As a result, they will always be able to lay the responsibility for failure to fulfil their programmes on the shoulders of their coalition partners. The absence of practical sanctions and the absence of "reality checks" enable them, due to the electoral effect, to irresponsibly demand any type of reform, including that which is ultimately unattainable.

Moreover, the necessity of making compromises with coalition partners leads parties toward the uncompromising extremes of exaggeration as they attempt to forge more space for retreat. Each of the coalition partners will have a tendency to follow the principle: ask for more so you can at least get something. Parties without a majority vocation thus logically drift into demagogy.

It is indisputable that one of the aims of a well functioning political democracy is the curtailment of demagogy and exaggerated propaganda. The operation of parties with a majority vocation (there may even be two such parties within the party system at one time) can also be found among established and relatively homogeneous coalitions of parties, which themselves may also have a majority vocation. Thus the two-party system is not a precondition. It is enough for there to be a system in which one party with a majority vocation competes with an established alliance which also has a majority vocation, or a system in which there are two stable coalitions, each with a majority vocation, competing against each other. ${ }^{4}$ This kind of established relatively homogeneous coalition, or alliance, may even include a small party as well.

right-wing populist parties, achieved a great election victory and moved the Christian Democrats (CVP/PDC) down to fourth place.

4) It is possible to ask whether the "two-and-a-half party system" (or imperfect bipartism) falls into this type of game, as seen in the example of Germany in the 1970s and 1980s. Bipolar configuration, alternation and a relatively moderate character of political competition could genuinely be supported, but at the same time the pendulum game of FDP reduced that which Schumpeter indirectly [1962: 272-273] and Popper directly [1988] considered rightly to be essential to a democracy, namely that citizens have the possibility to freely, by means of free elections, unseat the existing government. Which of the large parties, i.e. Social Democrats or Christian Democrats (SPD or CDU-CSU) will be the government and which the opposition was not so much decided on 30 
Relevant small parties are compatible with a well functioning democracy when they are integrated into the bipolar game of alternation [on alternation see Quermonne 1991 and 1995]. One might suggest that we are ignoring the frequently mentioned alternative to bipolar alternation, the broad or "grand" coalition, recommended by the theorist behind consociational democracy and the consensus model of democracy, Arend Lijphart. But we are not ignoring this at all. The broad coalition, which has demonstrated functional longevity only in the case of Switzerland, restricts the influence of small parties: small parties are in this system no longer relevant on a statewide (federal) level.

The size of parties is tied to the number of the parties in a given system. The likelihood that small parties will exist increases along with the increase in the number of parties.

\section{Criteria for Determining the Size and Strength of Parties}

The existence of different electoral systems can change the criteria by which a party may be considered small. For example, in Great Britain, the Liberals are a small party in terms of seats in the lower house of the Parliament, but they are not often a small party in terms of their share of the vote, which brings us to the question of the criteria involved in determining the size of a party.

If we wish to quantify the size and strength of a party, a variety of quantifying criteria is available, and they relate to the four various arenas: (1) membership strength, meaning the number of members and activists; (2) the size of the electorate, meaning the percentage of voters; (3) parliamentary size, meaning the percentage of seats in Parliament; (4) government strength (which we will deal with later in more detail).

The first criterion is of little use. By its standards, in 1998 the second smallest party in the Chamber of Deputies after the Freedom Union (US) was the Social Democratic Party (ČSSD), which however in the elections of that year became the strongest party. The number of members may be used to judge the development of one party, or to compare one party with the size of others that are similar. The French political scientists, Jean and Monica Charlot, further point out that the number of active members of a party can be used to measure its capability for political mobilisation, thus its "militant strength" (in the original French, "force militante") [Charlot and Charlot 1985: 499].

in Germany by the citizens through elections, but rather through the leaders of the small liberal party (FDP), and sometimes even during the legislative term, when they decided to transfer from one coalition (with SPD) to another (with CDU-CSU). Without denying the negative aspects of the two-and-a-half party system (especially from the viewpoint of the "non-classical" theory of democracy) it is possible with certain reservations to accept that this party system in which the small party of the centre plays a significant role works relatively well. However, there is no doubt that the two-party and two-coalition configurations function more satisfactorily (the latter on the condition that the coalitions are established and relatively homogeneous), as does the configuration in which an established alliance stands against one large party. In this case it can be asked how the German party system will function now when there are since the 1970s not only the Greens, but following unification also the East German post-Communists. The more pessimistic scenario is the fear that the system will tend to approach polarised pluralism and that the extreme postCommunists will be able to use blackmailing tactics. The more optimistic scenario is the prediction that in the Republic two moderate coalitions will alternate: (1) The Social Democrats with the Greens, against (2) The Christian Democrats with the Liberals. 
As for the second and third criteria, if we were analysing the evolution of popular opinion we would of course place more emphasis on the voter alone. However, as we are interested in understanding the role of parties within the state (or more generally within a given system, a category which can include, for example, the German Land, the Swiss canton, or the European Union), we will interpret the size of a party as meaning, in agreement with Duverger [1981: 381-382], its parliamentary size, i.e. the percentage of seats it holds in the lower chamber. Parliamentary strength also influences electoral strength. Voters in time would probably otherwise be disappointed to realise that the party they cast their votes for is being disadvantaged by the electoral system.

The strength of the parties (rather than their size) can also be measured in the arena of government, which for our purposes is even more important than the arena of Parliament. K. Janda [1980], in his overview of parties worldwide, characterised the governing strength of a party on the basis of two variables: (1) "Cabinet Participation", defined as the average number of ministerial posts held by a given party, (2) "Government Leadership", defined as the average number of years over time which a given party has occupied the highest post of executive power (the prime minister or president, depending on the type of regime). It is obvious that this "governing strength" is rather more a matter of "relevance" than of "size". If a small party has produced more than one prime minister does that mean it ceases to be small? Surely not. It is simply a party that is relevant.

The size of a party in the arena of Parliament, and the strength (or rather relevance) of a party in the arena of government are closely related to their coalition potential. This dependency is (1) material, which means that election coalitions can substantially increase the number of seats a party gains in Parliament. Here we can present two Czech examples, the first represented by KDS in 1992. Without the government coalition with the largest party (ODS), a situation advantageous to KDS, it would not have gained entry into the Czech National Council (which after the division of the Czecho-Slovak federation became the Chamber of Deputies of the Czech Republic).

In the case of the Czech Republic, elections into the Chamber of Deputies set the limiting threshold at $5 \%$ for individual parties, and then increase it in the case of election coalitions. This means that very small parties (such as KDS was) cannot form a coalition only among themselves, but must instead seek another, larger partner (a large, medium, or at the very least small party, but not another very small party).

The second Czech example can be seen in the November 1998 Senate by-elections, in which small and very small parties formed a successful four-party coalition (KDUČSL, US, ODA, DEU) composed of two small (KDU-ČSL, US) and two very small (ODA, DEU) parties. Of course we should remember that the Senate elections employ the double-ballot majority system.

(2) The dependency is also political which indicates the fact that a parliamentary and governing alliance increases or decreases the weight, or strength of a party. According to Duverger, in the French National Assembly between 1946 and 1951, the Communist party was less influential with its 163 deputies than the radical party with only 45 deputies. The Communists were isolated and alone, while the radicals made use of their position in the centre of the political spectrum to establish combinations and agreements.

In the Czech Republic during the second half of the 1990s, KDU-ČSL had the greatest coalition potential. However it failed to make use of this strength after the elec- 
tions into the Chamber of Deputies in June 1998, and for the first in a long time found itself in opposition.

\section{Big Roles for Small Parties}

Small parties can at times occupy a decisive position, providing them with considerable influence, when the difference in the number of parliamentary seats between the two main parties or alliances is very small. A coalition shift of the small party is enough to alter the political balance, a classic example is that of the German Liberals (FDP). For a long period, from the 1970 s to the 1990 s, they managed to maintain a position in government and occupy its key posts, while the two large parties, the CDU and the SPD, remained dependent on them. Thus the fate of the country was left in the hands of a small party. This situation of course depends on the character of the small party. Nonetheless, two fundamental questions present themselves: (1) Is this small party anti-system in nature and dangerous for democracy? (2) Does this small party have any kind of genuine social base? ${ }^{5}$

One of the ways to escape from being blackmailed by a small party in this manner is for the two largest parties to form a coalition between themselves, which in post-World War II Austria was often just the case. The large parties (Social Democrats - SPÖ and the People's Party - ÖVP) considered a coalition with the third party (FPÖ) as an unacceptable possibility, since in their eyes this party was nationalistic and extreme. (This type of coalition is not a matter of a grand coalition in the strict sense of the word - from the viewpoint of theory on coalitions it is instead usually a "minimal winning coalition", or more precisely a variant thereof, which unites the smallest number of parties necessary to win, i.e. to gain the majority of the deputy seats in the lower chamber of Parliament). Empirical evidence and theoretical explanations demonstrate that this type of "grand coalition" does not usually work well. A grand coalition blocks the political system; it prevents alternation and does not leave any institutional space for protest against the existing politics. ${ }^{6}$ In this way it also contributes to an extra-institutional overflow, an extreme example of which is organised terrorism, for instance in Germany at the turn of the 1960s [Braud 1997: 180].

${ }^{5}$ ) If a small party has a genuine social base, it has no choice but to accept this and to admit measures facilitating representation for these small parties. For example in Germany, the 5\% threshold is not applied to parties of national minorities, which relates mainly to the Danish minority in the northern Schleswig-Holstein. The German court in its constitutional verdict no. 32 of April 5, 1952, distinguished between on the one hand the fragmentary parties (Splitterparteien) which have an insignificant number of votes and have no local rooting (ohne ortlichen Schwerpunkt), i.e. they are scattered throughout the country and have no strong base in a single area, and on the other hand the minority parties (Minderheitsparteien), which the Danish party SSW in SchleswigHolstein actually is. The decision of the German constitutional court shows that this party of the Danish minority focuses on one fifth of the votes in a part of the country with a specific historical fate, and which is geographically clearly defined and where the cultural character is partly formed by the national minority. This kind of party is not a fragmentary party (Splitterpartei) [see Klokočka 1991: 175].

${ }^{6}$ ) This is fortunately not true for Switzerland, where the considerable federal decentralisation affects political parties as well and as such the deputies of "government" parties criticise their ministers with ease, and where in addition the elements of direct or semi-direct democracy facilitate the legal expression of disagreement and protest. 
It be may asked whether or not it is prospicious to democracy when a small party representing only a very limited circle of voters plays such a large role in the political system. A party that has gained only five percent of the popular vote or even less is in a position to determine which of the large parties will be in government and which in the opposition, moreover it is even able to do this throughout the course of the legislative period, i.e. without any reference to elections. Governments become quite fragile and the large parties are left dependent on the small ones.

A small party can dictate its conditions because the large party is unable to govern alone. In this way it can abuse its position and select among the potential coalition partners the one which is most likely to retreat or makes the best offer, and the small party can then, for instance, even acquire the seat of prime minister. In June 1998, it was in fact the post of prime minister that the then leader of the People's Party (KDU-ČSL), Josef Lux, was striving for in his wish to form a coalition with the Social Democratic Party (ČSSD) and the small Freedom Union (US) following the 1998 elections into the Chamber of Deputies.

The likelihood of establishing a clear and homogeneous majority decreases when small parties play in a disproportionately large role, and the political accountability of the government toward citizens-voters is diluted. As K. R. Popper [1988] pointed out, the voter is then to a great extent stripped of the power to sanction the existing governing team.

In practice this is a matter of deciding whether to give an advantage to the strongest party (or durable alliance) and thus increase the chances for a stable and accountable government, or whether we will let the small parties play a disproportionate role and use their power to unscrupulously blackmail the large parties and topple the government whenever they wish.

Moreover, the representativeness that supporters of the proportional system put such an emphasis on is only expressed in the forum of Parliament. However, in terms of the exercise of power, the government is of more significance than Parliament. Parliament primarily plays the role of checking power. Insofar as any certain (though usually only very rough) proportionality in government is concerned, it is an altogether rare phenomenon (lastingly it has occurred only in Switzerland since 1959, where of course the small parties have been permanently excluded from the federal executive), and most often it is an expression of some sort of crisis situation (for instance in Great Britain during both World Wars when governments of national unity were formed, or in Austria where over the last decades the Social Democrats (SPÖ) have generally governed along with the People's party (ÖVP), because there are difficulties involved in forming a coalition with the third party (FPÖ), which is extreme and nationalistic).

\section{Small Parties in the Czech Political Scene}

On the basis of the two previous elections to the Chamber of Deputies of the Czech Republic (regular elections in 1996 and early elections in 1998), the following configuration emerged: the two largest parties (the right-wing ODS and the Social Democrats C SSD) attained roughly $30 \%$ of the popular vote or just short of that, one medium-large antisystem party without coalition potential (KSČM, i.e. dogmatic Communists who have maintained their name), which won just under $15 \%$ of the votes, and finally two (after the 1996 elections three) small parties who gained between 6-9\% of the vote. 
The extreme right wing party (SPR-RSČ) was during the legislative period of 1996-1998 a small, anti-system party and had absolutely no coalition potential. The small liberal right parties (ODA in the legislative period 1996-1998, and US in the legislative period 1998-2002) which could more or less be characterised as small parties of personalities but nonetheless ideologically clearly defined as positioned on the right, which rather lowered their coalition potential. KDU-ČSL, which on the Czech political landscape is the party with the second largest number of members after the Communists (KSČM), has a pivotal position as a result of its position in the centre of the political spectrum and also had the highest coalition potential, which is usual among these kinds of Christian-Democratic parties.

Overall the Czech political scene is quite "polarised" in the sense that Sartori uses the word, i.e. between the relevant parties exists a considerable ideological (or other) distance. This complicates the formation of a coalition not only with the anti-system party but also even with other parties. For example, during the election campaign of 1998, the leader of the Social Democratic Party (ČSSD), Miloš Zeman, declared on more than one occasion that following the legislative elections the only potential coalition party for ČSSD could be KDU-ČSL alone and no other party. The right-wing parties also limited themselves prior to the elections, particularly ODS, which affectedly "mobilised" itself against the Social Democrats during the campaign, as though the latter were a threat to the changes that had been achieved since 1989 .

Both legislative elections in the Czech Republic (1996 and 1998) were followed by the formation of minority governments. The first was made up of the strongest party ODS (29.6\% of the votes, $34 \%$ of the seats) and two small parties (KDU-ČSL with $8.1 \%$ of the votes and $9 \%$ of the seats, and ODA with $6.4 \%$ of the votes and $6.5 \%$ of the seats). These three parties together still were unable to make up an absolute majority of seats (they only had $49.5 \%$ of the seats). This minority government collapsed in November 1997 after the two small parties (KDU-ČSL and ODA) withdrew from the coalition, and roughly half of the deputies and several ministers left the largest party, ODS. After the government of Prime Minister Václav Klaus, the leader of ODS, was dissolved, an interim, minority 'semi-caretaker' government was formed and named by the president of the Republic, composed mainly of members from smaller political parties and those politicians who had left ODS, as well as seven non-affiliated members. The prime minister was Josef Tošovský, the governor of the Central Bank, who had no party affiliation (though he was formerly a longtime member of the Czechoslovak Communist Party during the grim period of "normalisation", a fact which Czech citizens became aware of only some time after he had been appointed prime minister, and then only due to the investigative efforts of some journalists).

At the end of January 1998, this government acquired the support of the Chamber of Deputies primarily through the help of the Social Democrats (ČSSD), a party that from the end of 1997 had been coming first in all opinion polls carried out at the time. The Social Democrats, though not actually participating in this government themselves, nonetheless "tolerated" it temporarily and on the condition that early elections would be called in June 1998. In order for these early elections to be called within the agreed time frame, ČSSD along with ODS, which also shared concerns about the interim Tošovský government perhaps implementing important irreversible measures, together put forth a constitutional law on shortening the term of parliamentary mandates [see Brokl and Mansfeldová for details]. The early elections were ultimately held in 1998, and although in accordance 
with all expectations ČSSD did gain the most votes, it acquired only $37 \%$ of the seats. It was still unable to form a majority government.

The difficulties involved in setting up an efficient government and establishing stability were predicted by this author as early as 1996 [Novák 1996b], i.e. prior to the legislative elections in June of 1996, as a reaction to the expressed satisfaction of the then prime minister, Václav Klaus, who emphasised the political (in fact more precisely the governmental) stability of the Czech Republic. Elections into the Chamber of Deputies in 1996 unfortunately at that time confirmed the author's fears concerning the uncertain future of government stability.

On the basis of the 1996 results, the level of fragmentation did decrease ("only" six parties gained entry to the lower chamber and the effective number of parties was 4.15), the process of crystallising the party scene in the meantime strongly progressed: on the right side of the political spectrum with the merging of KDS and ODS, and even more so on the left side of the spectrum where ČSSD dominated sovereignly. Despite all this, the political scene after the 1996 elections became substantially less "governable" than it had been after the 1992 elections. The concern [see Novák 1996c] that the configuration during the years 1992-1996 was an exceptional one and that the likely mid-term (or even long-term) future of the Czech political scene would be characterised by governmental weakness or government instability was confirmed. A significant improvement of the socio-economic situation (which in the Czech Republic as is known began to worsen perceptibly from 1997 on) was not to be expected. Clearly, ODS and ČSSD have difficulties in setting up a functional and efficient government, which in the period of transition the Czech Republic particularly requires. A minority government in the absence of a dominant party ${ }^{7}$ is extremely fragile.

\section{Increasing Proportionality}

A process of gradually increasing proportionality in elections into the Chamber of Deputies began to express itself from this time [see Novák 1996c: 410-412]. This arose as a result of the combined mechanical and psychological effects of the 5\% threshold. For a majority of more than half of the parliamentary mandates it is now necessary under the existing electoral law to gain roughly $45 \%$ of the popular vote which is very difficult both for the Social Democrats and for a right-wing coalition, which would not be very solid at

\footnotetext{
${ }^{7}$ ) According to Duverger's view it appears that only the presence of a dominant party, as he defines it in his classic work on political parties, i.e. a party substantially larger than any other party in the given political system [Duverger 1981: 412-414] facilitates the formation of a long-term (stable) minority cabinet, which would not have the character of a mere caretaker government. This is true in the Scandinavian countries where the Social Democrats represent this type of dominant party. The research of Schofield seems to confirm this, according to which in Sweden during the period of 1945-1987, out of the overall number of sixteen governments ten were minority, and minority governments lasted there on average thirty months, i.e. two and a half years, which is an acceptable average [Schofield 1995: 251]. For a discussion on whether Duverger's definition of the dominant party differs from how for example Blondel interprets a dominant party, how it differs from Sartori's "predominant" party, and Schwartzenberg's "ultradominant" party [Schwartzenberg 1977: 578], as well as from the idea of parties with a "majority vocation", see my handbook [Novák 1997: 162]. Here it is enough to point out that the dominant party in the sense Duverger applies it can only appear once in a given system, but it need not have an absolute majority of deputy seats.
} 
any rate. ${ }^{8}$ In addition, the extreme, anti-system parties, KSČM and SPR-RSČ, passed over the threshold without difficulty in these elections.

After the early elections to the Chamber of Deputies in June 1998 the situation changed. Both right-wing parties (ODS and ODA) had been hit by crises, from which ODA probably never recovered, and the party did not even candidate in the early elections to the lower chamber. A large number of deputies and ministers left ODS at the end of 1997 and the beginning of 1998, with the former minister of the interior, Jan Ruml, leading the way. He in turn then founded a new formation, the Freedom Union (US), which after a promising start, ultimately receded, and in the early legislative elections in June represented the weakest party managing to cross the 5\% threshold (at $8.6 \%$ ) and enter into the Chamber of Deputies. Conversely, after the departure of a number of the most prominent representatives from ODS, the position of its founder and leader, Václav Klaus, was further strengthened, and in the early elections ODS lost only about $2 \%$ (as compared with the previous legislative elections of 1996). With a gain of $27.7 \%$ of the popular vote it trailed behind the winning ČSSD $(32.2 \%)$ by not even five percentage points.

Party fragmentation and polarisation was on this occasion lessened as a result of the failure of the extreme right-wing SPR-RSČ, which surprisingly did not manage to cross over the 5\% threshold, and thus did not gain any seats in the lower chamber. As a result only five parties won seats in the Chamber of Deputies, one party less than in 1996. Following the 1998 early elections the effective number of parliamentary parties was only 3.7, which is a positive development. The Czech party "landscape" thus moved closer to what Sartori refers to as moderate pluralism. But again, even in this case, a majority government could not be set up.

\section{Are the Interests of Large Parties at the Same Time the Interests of the Czech Republic?}

Already in 1996, prior to the legislative elections, I stressed [see Novák 1996a] that the Social Democratic Party and ODS ought to realise the fact that it is in their interest - as well as the interest of the Czech Republic and its future long-term government stability to modify the electoral law on elections into the Chamber of Deputies, in order to facilitate the formation of an efficient and functional government. Otherwise, despite a number of positive circumstances, the Czech political system could sink into the "mud of centrism" (Duverger) and powerlessness. In addition to the existence of a fragile minority government, I described an even worse picture: a "grand coalition" of ODS and ČSSD which would entirely block the Czech political system, disgust the population, and throw coal onto the fires of extreme parties.

The two largest Czech parties (ODS in particular) realised this under the pressure of difficulties in forming government coalitions only after the elections of 1998, and their leadership began to consider the possibility of together proposing that changes be made to

8) In 1992 the coalition of the centre-right (ODS-KDS, ODA, KDU-ČSL) with a mere 42\% of the votes acquired an absolute majority of deputy seats (52\%). In these parliamentary elections $19 \%$ of the votes were wasted (and were redistributed). Conversely, in the following parliamentary elections in 1996 only $11 \%$ of the votes were lost, and for the similar coalition of three parties (ODS, ODA, KDU-ČSL) the $44 \%$ of the votes was not enough to gain an absolute majority in Parliament (they obtained only $49.5 \%$ of the seats) and for this reason were forced to form a minority government. 
the electoral law for the lower chamber. It is well known that ODS (which originally proposed a single-ballot plurality electoral system of the Westminster type) was more inclined toward these changes than were the Social Democrats, whose share of the voting preference moreover considerably dropped in the second half of 1999. The main source of conflict during the long negotiations between the two parties concerned the method of allocating seats: ODS proposed the Imperiali highest average system, ČSSD the d'Hondt system. In the end a compromise was reached in the form a sort of modified d'Hondt system, the effects of which lie somewhere between the d'Hondt and the Imperiali systems. The Social Democrats proposed that the new law should only come into effect as of January 1, 2002, fearing that ODS might quit the "opposition agreement", the result of which could lead to the fall of the minority, Social-Democratic government and the call for new, early elections (the next regular elections into the Chamber of Deputies should be held in 2002).

Only on January 26, 2000 did the leadership of ODS and the Social Democrats (Václav Klaus and Miloš Zeman, as well as the deputy chairmen of the parties and of the parliamentary clubs), in an effort to append and deepen the agreement on creating a stable political environment, together signed the written "agreement no. 2 on the basic parameters of changes to the electoral system concluded by the Czech Social Democratic Party and the Civic Democratic Party". According to agreement no. 2, the number of electoral constituencies would increase from 8 to 35 , the method of allocating seats would be changed from the Hagenbach-Bischoff to the modified d'Hondt system, ${ }^{9}$ and the overall number of mandates in the Chamber of Deputies would remain at 200. According to the agreement the electoral constituencies may not cross over the borders of the regions, and their borders should be formed out of the districts, which limits the possibilities of arbitrary "gerrymandering". This proposal was to be submitted by the government to the Chamber of Deputies where it would be debated and passed no later than July 31, 2000, after which the modified electoral law would come into effect in January 1, 2002. This proposed compromise represents a profound change in comparison with the existing situation.

9) This refers to the aforementioned modified d'Hondt system, in which the first divisor is not 1, but 1.42. In small electoral constituencies this method helps large parties more than they are helped by the normal d'Hondt system, but less than the Imperiali highest average system. 


\section{Possible Coalitions after the Early Parliamentary Elections of 1998}

Table 1. The results of the elections into the Chamber of Deputies in the Czech Republic (Given that the overall number of seats is 200 it is easy to calculate the percentage of parliamentary seats so that the number of seats is divided by two.)

\begin{tabular}{lccccccc} 
& ČSSD & ODS & KSČM & KDU-ČSL & US & SPR-RSČ & ODA \\
\hline 1996 & 61 & 68 & 22 & 18 & - & 18 & 13 \\
1998 & 74 & 63 & 24 & 20 & 19 & 0 & - \\
\hline
\end{tabular}

The Communists (KSČM) and the extreme right-wing (SPR-RSČ) have zero coalition potential and are for this reason excluded from any possible government coalitions here.

Minority government of Václav Klaus 1996-1997

ODS, KDU-ČSL, ODA $\quad(68+18+13=99$ out of 200 seats, i.e. $49.5 \%)$

Minority government of Miloš Zeman 1998- ?

ČSSD (74 seats, i.e. $37 \%$ )

As, for example, L. C. Dodd [1976] pointed out, "minimum winning cabinets" are more propitious to government stability than "undersized cabinets" (i.e. minority governments), and even more than "oversized cabinets". If we take into consideration the fact that KSČM (the un-renamed dogmatic Communist party) has zero coalition potential and is thus excluded from all government coalitions, the following minimal winning coalitions in particular could theoretically have been considered after the Czech legislative elections of 1998:

1) $O D S+K D U-\check{C} S L+U S(63+20+19=102$ seats, i.e. $51 \%)$

This is the minimum winning coalition with the least number of seats, according to the interpretation of W. H. Riker [1962], and at the same also the minimal connected winning coalition (the minimal coalition of parties neighbouring one another on the political spectrum), according to the interpretation of J. Axelrod [1973]. The reasons why this coalition (by far the most logical one on paper) of the centre-right has never been achieved are evident: the Freedom Union - US (headed by its then leader Jan Ruml) is to a large extent composed of politicians who in 1997 abandoned ODS, and KDU-ČSL is the party which in 1997 through its departure from the at that time similar centre-right coalition of ODS + KDU-ČSL + ODA brought about the fall of the Klaus government. The leaders of the two small parties (Josef Lux and Jan Ruml) were among the main engineers behind the fall of the Klaus coalition minority government. Is it any wonder then that none of the leaders of the three parties mentioned here was interested in forming a coalition together?

2) $\check{C} S S D+K D U-\check{C} S L+U S(74+20+19=113$ seats, i.e. $56.5 \%)$

The leader of KDU-ČSL at the time, Josef Lux, as well as the president of the Republic, Václav Havel, demonstrated a preference for this type of coalition, but it never came about because the right-wing Freedom Union of Jan Ruml rejected not only a government but also any sort of parliamentary coalition with the Social Democrats of Miloš Zeman. It is no real loss that this planned, heterogeneous coalition composed of one left-wing party (ČSSD), one right-wing party (US) and one party from the centre (KDU-ČSL) was in the end never realised. It is not positive to witness that nothing other than their mere antago- 
nism to the Civic Democratic Party (ODS) of Václav Klaus would be able to unite the leaders of these three parties, J. Lux, M. Zeman and J. Ruml. A great ideological distance lay between the right-wing US and the left-wing ČSSD, not mentioning the personal enmity between the leaders of these two parties. Nevertheless, it cannot be entirely denied that this is one of the possible minimal connected winning coalitions, assuming that US sits less to the right on the left-right scale than ODS, which is not entirely certain.

3) $\check{C S S D}+\operatorname{ODS}(74+63=137$ seats, i.e. $68.5 \%)$

This theoretical possibility which has usually been referred to (though not entirely appropriately) as the "grand coalition" because it unites the two strongest parties, would in reality be a minimal winning coalition drawing in the fewest number of parties, according to the interpretation of M. A. Leiserson [1968]. Its apparent disadvantage would be the large ideological distance between the two parties. Both of these two parties however were united by a common interest in restricting the influence of small parties and also the common interest of limiting the manoeuvring space of the president of the Republic, whose role in the difficulties involved in forming governments has increased and whose distaste with the large political parties has long been apparent [see Brokl and Mansfeldová 1999].

\section{Representation of the Ministers of Small Parties in the Two Klaus Governments}

Another circumstance playing a role here is that of the negative experiences taken from the previous coalition governments of the centre-right (Klaus I and Klaus II). Among other factors, the distribution of ministerial portfolios was important. Let us recall that the first Klaus government was set up at the time when the Czecho-Slovak federation was coming to an end in 1992, but the federal government was no longer of significance, while the national governments, i.e. the Slovak government of Mečiar and the Czech government of Klaus, actually were.

The Czech national government, the prime minister of which was Václav Klaus, was installed on July 3, 1992. After the Czecho-Slovak federation was dissolved (January 1, 1993), this government turned into the new government of the independent Czech state, at which time, on January 4, 1993, two more ministries were set up - the Ministry of Defence and the Ministry of Transportation. These two ministries, during the federation period, existed only on the federal level and did not form an element in the Czech government (by way of note, Jan Stránský became the Minister of Transportation, who up until the dissolution of the federation had been the prime minister of the federal government).

Table 2. The party composition of the first Klaus government installed on July 4, 1992 (status January 4, 1993, i.e. after the disintegration of the Czecho-Slovak federation and the addition of the two new ministries)

\begin{tabular}{lcccccc} 
& \multicolumn{3}{c}{ Parliamentary seats } & \multicolumn{2}{c}{ Cabinet posts } \\
Party & $\mathrm{N}$ & \% of total & $\%$ of coalition & $\mathrm{N}$ & $\%$ \\
\hline ODS & 66 & 33 & 63 & 10 & 52.5 \\
KDU-ČSL & 15 & 7.5 & 14 & 4 & 21 \\
ODA & 14 & 7 & 13 & 3 & 16 \\
KDS & 10 & 5 & 10 & 2 & 10.5 \\
Total coalition & 105 & 52.5 & 100 & 19 & 100
\end{tabular}


Václav Klaus, the leader of the strongest party ODS, became the prime minister of the Czech government, while the leaders of the small parties ODA (Jan Kalvoda) and KDUČSL (Josef Lux) each obtained the post of Deputy Chairman of the government. It is clear from the table that this distribution of ministerial portfolios was applied so that ODS, which alone represented roughly $63 \%$ of the coalition seats, would obtain only a small majority of the ministerial portfolios: 10 out of 19 , i.e. only one seat more than what was left for the small parties, which constituted roughly $52.5 \%$ of the overall number of ministerial posts. The distribution of ministerial portfolios thus was not proportional to the parliamentary size of the coalition parties. All the small parties were overrepresented in government, while the largest coalition party (ODS) was underrepresented, though it nonetheless had the narrowest possible absolute majority in the cabinet.

The advantage small parties had against the largest party, ODS, was in reality even greater than the numbers would indicate. It is necessary to add too that KDS entered Parliament only as a result of its pre-election coalition with ODS. The very small KDS (the Christian-Democratic party of Václav Benda) had only 1-2\% of the votes according to polls conducted in 1992, while at the same time the 5\% threshold necessary for gaining seats in Parliament still existed! In its own way it is a paradox that it was this generosity on the part of ODS toward KDS that later proved fateful for the largest party.

In an effort to survive, politicians from the miniature party KDS began to consider a fusion with ODS, which actually came about in March 1996, i.e. several months before the next legislative elections. The result was that the ministers from KDS, in the case of conflicts between the ministers of ODS with ministers from the small parties KDU-ČSL and ODA which occurred from time to time, had a growing interest in not voting along with ministers from the other small parties, but instead voting with the ministers of the largest party.

The ministers from KDU-ČSL and ODA had difficulty coming to terms with the fact that during conflicts within the government they were easily overruled, and they decided that in future, i.e. after the elections into the Chamber of Deputies in 1996, they would demand to receive among them half of the ministerial portfolios. They genuinely achieved this, but in these elections the old-new coalition (ODS + KDU-ČSL + ODA, i.e. without KDS which had in the meantime fused with ODS) lost its absolute majority of deputy seats. This was the swan song of the second Klaus government. As is well known it was the very next year, in 1997, that the second Klaus cabinet fell.

Table 3. Party composition of the second government of Václav Klaus installed on July 25, 1996

\begin{tabular}{llcccc} 
& \multicolumn{3}{c}{ Parliamentary seats } & \multicolumn{2}{c}{ Cabinet posts } \\
Party & $\mathrm{N}$ & \% of total & \% of coalition & $\mathrm{N}$ & $\%$ \\
\hline ODS & 68 & 34 & 69 & 8 & 50 \\
KDU-ČSL & 18 & 9 & 18 & 4 & 25 \\
ODA & 13 & 6.5 & 13 & 4 & 25 \\
Total coalition & 99 & 49.5 & 100 & 16 & 100
\end{tabular}




\section{The “Opposition Agreement" and its Critics}

It is little wonder that, after the post-election negotiations had demonstrated that the relations between the right-wing ODS and the small parties of the right and centre (US, KDU-ČSL) were still tainted by events of the past and remained considerably tense, ODS decided instead to "tolerate" the minority "monochromatic" government of the Social Democrats (ČSSD), and in July 1998 reached an "agreement on creating a stable political environment" with them. According to this agreement both contracting partners must, among other things, submit within one year after signing the agreement:

"A proposal for such modifications to be introduced into the constitution and other laws which more precisely determine the competence of particular constitutional organs, the process involved in their establishment, and in accordance with the constitutional principles strengthen the importance of the results emerging out of the competition between political parties".

With this, ODS did not even enter into the government, nor did it engage in supporting the minority Social-Democratic government in Parliament during voting on their proposals. ODS limited itself to the recognition of the right of the strongest party to establish a minority government, and it committed itself to not take part in votes of confidence (either for or against), and further to not instigate or support any motion of no confidence in the government. In this way it enables (in the case of both parties maintaining the aforementioned agreement) the minority government of the Social Democrats to remain in power for the entire legislative term of 1998-2002. In return, according to the agreement, the opposition party has the right to occupy, among others, the positions of speakers in both chambers of Parliament of the Czech Republic, as well as other positions of controlling organs in the Chamber of Deputies. In the agreement between C SSD and ODS, two articles are of particular importance:

"I. The parties named above commit themselves to respecting the right of that party of the two which is victorious in the elections to set up the government of the Czech Republic, and to express this respect through the non-participation of the deputies of the second party during government confidence voting."

"VI. Each of the parties named above commits itself to not calling for government confidence votes and not making use of constitutional opportunities leading to the dissolution of the Chamber of Deputies during the legislative period of the Chamber of Deputies, and should such proposals be submitted by another political entity, will not support the vote. In the case of votes on individual laws (including the budget) the aforementioned parties are not bound in any way."

The agreement between ČSSD and ODS - and especially their common effort to strengthen the position of large parties and weaken that of small ones - provoked a great deal of criticism and concern, as well as a variety of interpretations in the Czech Republic. On occasion it is possible to come across the opinion in some Czech publications that the "real opposition" is formed by KDU-ČSL, US and KSČM, while the "agreement opposition" (ODS) actually represents a sort of "hidden or silent coalition" with ČSSD, that the "agreement on creating a stable political environment" camouflages or masks the real state of affairs, which is a "grand coalition" between ODS and ČSSD [Klíma 1999: 14].

If we divide the concept of a coalition into election, parliamentary and government versions, it is clear that in the given case it is not a matter of an election or a government coalition. It is only possible to think in terms of some sort of parliamentary coalition. The 
analysis of voting by individual parliamentary groups (deputy clubs) in the years 1998 and 1999 moreover demonstrates that it was not the deputies from the "contracting" ODS who most frequently voted with ČSSD, but rather the deputies from the Communist Party (KSČM) and deputies from the Christian Democratic Union (KDU-ČSL), i.e. deputies from the assumed "real opposition". ${ }^{10}$

Pehe [1999] among others warned that changes to the electoral law which ČSSD and ODS negotiated on could as a result "lead to the return of the Communists to power". The proposed modifications (increasing the number of electoral constituencies from 8 to 35, substituting the Hagenbach-Bischoff method with the modified d'Hondt system) would instead weaken the Communists, who usually represent the third largest party. The modifications that have been proposed would lead to a system which in terms of its effect approaches the single-ballot plurality system of the Westminster model. Though it is true that since the second half of 1999, polling agencies have recorded a drop in the electoral support for the Social Democrats (ČSSD) and a parallel, large rise in the electoral support for the Communist party (KSČM), which at the time was competing with ODS for first place as the favourite among Czech voters. But even if the electoral support for the two largest parties (ODS and ČSSD) was drastically decreased while that for the communist party (KSČM) increased enough to surpass that of the two largest parties, it would suffice to create a (pre-) election coalition (for instance, ODS + US and/or ČSSD + KDU-ČSL, in an extreme case ČSSD + ODS) in order to marginalise the Communists, who have no potential coalition partner. Moreover, it might not even be necessary to create a preelection coalition, and instead be sufficient to set up a post-election (government or parliamentary) coalition of non-Communist parties. This would prevent any possible Communist government from obtaining the confidence of Parliament, even if in the next elections into the Chamber of Deputies, which should be held in 2002, the Communists came out in front and acquired a relative majority (plurality) of seats. ${ }^{11}$ The agreement

10) The extension, appending and strengthening of this agreement on creating a stable political environment is the so-called "Common declaration of the delegation of ODS and ČSSD of January 14,2000 ", according to which both participating parties consider it essential to agree on four points: (1) on the state budget, (2) on the basic parameters of the change to the electoral system, (3) on the preparation of the Czech Republic for entry into the European Union, (4) on the determination of the objective conditions of tolerance of the minority government, (5) on communication between parliamentary clubs. In this "common declaration" of January 14, 2000 is stated: "In the case of the successful completion of preparation and signing of the first part of these written agreements ODS facilitates acceptance of the state budget in the first \{parliamentary\} reading, and after signing the remaining agreements facilitates the final passing of the state budget for the year 2000." If then the five mentioned agreements were realised the result would be a certain shift in the continuum in the direction from purely procedural "agreements" toward a normal parliamentary coalition.

11) According to the Czech constitution a newly named government must present itself before the Chamber of Deputies within thirty days of its being appointed and request a vote of confidence (article 68). If the Chamber of Deputies rejects the request of the government for a vote of confidence, the government must resign (article 73). Finally, should the government refuse to resign, even though it is obliged to do so, the President must dismiss the government (article 75). It is possible then to say that the Czech Republic belongs among those countries in which the newly formed government necessarily requires an explicit formal legislative investiture vote. Kaare 
partners, ODS and ČSSD, and eventually even other non-Communist parties, could certainly reach such an agreement on a post- or pre-election coalition.

Pehe [1999] claims further that the shift in the direction toward a two-party system need not be as particularly advantageous to ODS as its representatives may think. The two-party system forces both main parties into becoming broad coalitions with an assortment of interest and political groups, and leads to a certain "ideological wishywashiness", and rules out "relatively rigid" disciplined parties with strong leaders, such as that which ODS and Václav Klaus currently represent. What Pehe is presenting in reality relates to the American presidential regime, in which the main parties are not disciplined. It is not, however, valid for two-party systems in a parliamentary regime, as the classic example of Great Britain in particular demonstrates, in that both main parties are relatively disciplined and strong leadership is also possible, and the Czech Republic has of course a parliamentary regime.

The two-party system is not at any rate a particularly likely possibility in the case of the Czech Republic, not even after the (at present uncertain) change to the electoral law which the leadership of CSSD and ODS agreed on in January 2000. A mathematical simulation of the parliamentary elections of 1996 and 1998 [see Lebeda 1998] shows that a combination of small electoral constituencies (in this case 38) with the Imperiali highest averages system would lead in the Czech Republic under the configuration at the given time, when ODS and ČSSD were in election terms essentially stronger than the other parties, almost certainly to a two-party system. However, this is based on the assumption that the small parties would move into the elections independently, as is the case under the current electoral law. But a change to the electoral law would in all likelihood bring about the formation of pre-election coalitions among the small parties out of their interest in maintaining a position in the Chamber of Deputies. The arrangement would prevent the emergence of a two-party system and thus most likely lead to a two-and-a-half party system.

Pehe himself also shows that if the small parties of KDU-ČSL and US were to form a pre-election coalition they could in fact defeat both large parties. Indeed this is possibly true, especially if ČSSD continues to fall, as in the polls taken during the last months of 1999 and the early months of 2000 . But Pehe is incorrectly making a reference to the success achieved by the four-party coalition (KDU-ČSL + US + ODA + DEU) formed in the 1998 Senate elections. Senate elections are held according to the doubleballot (absolute) majority system, which favours parties with high coalition potential. Unlike this, the proposed modifications to the system of proportional representation and its effects, as is known, more closely approach the single-ballot plurality electoral system which does not help parties with high coalition potential, but rather the two largest parties, and then those parties that are strongly concentrated in a region.

If we proceed from a situation in which KDU-ČSL and US were to form a preelection coalition (whether only between the two of them, or in the form of a four-party coalition including the very small parties ODA and DEU), and as the basis of an estimate of the electoral strength of the parties we take the development of support in the polls during the last months of 1999 and the early months of 2000, then, with the electoral law

Strøm [1990] showed correctly that the necessity of an explicit legislative investiture vote complicates the formation of minority cabinets. 
changed according to the proposal of ODS and ČSSD, in all likelihood four political entities would have a chance to gain seats in the Chamber of Deputies (three parties plus one coalition of two or four parties). Three of these parties (ODS, KSČM and the four-party coalition) have according to polling agencies at present around $20 \%$ of the electoral support, and the fourth (ČSSD) has not quite $15 \%$. This kind of configuration (in which the anti-system KSČM would be fighting over first place among the three strongest parties) is less favourable than the ones for the periods prior to the elections in the Chamber of Deputies in 1996 and 1998, and it aggravates the prognoses. If the reverse happened and KDU-ČSL and US each ran on their own candidate list, the right-wing US would probably then become the most under-represented party out of all the parties now (in the legislative period 1998-2002) represented in the Chamber of Deputies, while at the same time KDU-ČSL, which has a strong base in several regions, would probably be less harmed by this type of modified electoral law.

\section{Conclusion}

In the Czech Republic, the results of voter support, as shown in the polls since 1995, and the results of elections to the Chamber of Deputies since 1996, have shown that two parties have asserted themselves considerably more strongly than the others - the moderately right-wing ODS and the moderately left-wing CSSD. However, both parties have encountered difficulties in setting up a relatively homogeneous and stable majority government. One of the obstacles remains for the time being the rather large distance (ideological and other) between the relevant parties. The second obstacle is the increasing proportional effect of the existing law for elections into the Chamber of Deputies. Under such circumstances, a strengthening of the majority elements while preserving the PR system could play a positive role. It would not hurt Czech democracy if the two largest parties were to considerably strengthen at the expense of the small parties, quite the reverse it would probably contribute to its consolidation. However, the large decline in support for ČSSD and the parallel increase in support for the Communist party (KSČM), which has appeared in the polls since the second half of 1999, significantly complicates the situation and it makes it difficult to form a clear prognosis.

\section{Appendix: Czech Abbreviations and English Full Names of Czech Parties}

ČSSD Czech Social Democratic Party

DEU Democratic Union

KDU-ČSL Christian Democratic Union-Czechoslovak People's Party

KSČM Communist Party of Bohemia and Moravia

ODA Civic Democratic Alliance

ODS Civic Democratic Party

SPR-RSC Association for the Republic-Republican Party of Czechoslovakia

US Freedom Union

Translated by Robin Cassling

MiroslaV NovÁK (Doctor of Sociology, University in Geneva) is an associate professor of political science at Charles University in Prague. He specialises in comparative political sociology, with a particular focus on the transition to democracy of the post-communist countries of Central and Eastern Europe, party systems and electoral systems, and types of democracy. He is 
the author of two academic books in French and one in Czech. Among the journals in which his work has been published are the Revue internationale de politique comparee and the Czech Sociological Review.

\section{References}

Axelrod, J. 1997. Conflict of Interest. A Theory of Divergent Goals with Application to Politics. Chicago: Markham.

Blondel, J. 1968. "Party Systems and Pattern of Government in Western Democracies." Canadian Journal of Political Science/Revue canadienne de science politique 1: 183-203.

Blondel, J. 1990. Comparative Government. An Introduction. New York and London: Philip Allan.

Braud, P. 1997. Science politique. 1. La démocratie. Paris: Seuil.

Brokl, L., Z. Mansfeldová 1999. "Czech Republic.” Prepared for European Journal of Political Research Political Data Yearbook (forthcoming).

Charlot, J. 1974. "Faut-il interdire les petits candidats?” Projet no. 87: 837-841

Charlot, J., M. Charlot 1985. "Les groupes politiques dans leur environnement." Pp. 429-495 in Traité de science politique (vol. 3), ed. par M. Grawitz et J. Leca. Paris: PUF.

Dodd, L. C. 1976. Coalitions in Parliamentary Government. Princeton: Princeton University Press.

Duverger, M. 1981. Les partis politiques. Paris: A. Colin (10th edition, first edition 1951), coll. Points.

Fisher, S. 1974. The Minor Parties of the Federal Republic of Germany: Toward a Comparative Theory of Minor Parties. Hague: Martinum Nijhoff.

Ignazi, P. 1992. "The Silent Counter-Revolution.” European Journal of Political Research 22: 334.

Inglehart, R. 1977. Silent Revolution: Changing Values and Political Styles among Western Politics. Princeton: Princeton University Press.

Janda, K. 1980. Political Parties, a Cross-National Survey. New York: The Free Press.

Klíma, M. 1999. "Nepřirození spojenci” [Unnatural Alliances]. Nová Přitomnost March, 12-15.

Klokočka, V. 1991. Politická reprezentace a volby v demokratických systémech [Political Representation and Elections in Democratic Systems]. Prague: Aleko.

Lane, J.-E., S. Ersson 1999. Politics and Society in Western Europe. London: Sage (fourth edition, first edition 1987).

Laurent, A., B. Villalba (eds.) 1997. Les petits partis. De la petitesse en politique. Paris: L'Harmattan.

Lebeda, T. 1998. "Vládní stabilita v České republice a volební systém poměrného zastoupení" [Government Stability in the Czech Republic and the Electoral System of Proportional Representation]. Politologický časopis 5: 115-136.

Leiserson, M. A. 1968. "Factions and Coalitions in One-Party Japan: An Interpretation based on the Theory of Games." American Political Science Review 62: 770-778.

Mair, P. 1991. "The Electoral Universe of Small Parties in Postwar Western Europe". Pp. $42-70$ in Small Parties in Western Europe. Comparative and National Perspectives, ed. by F. MüllerRommel and G. Pridham. London: Sage.

Müller-Rommel, F., G. Pridham (eds.) 1991. Small Parties in Western Europe. Comparative and National Perspectives. London: Sage.

Novák, M. 1996a. "Démocratie et efficience(s). Y-a-t-il un choix constitutionnel supérieur à tous les autres?" Revue internationale de politique comparée 3: 689-712. 
Novák, M. 1996b. "Malá politologická úvaha o vládní stabilitě" [A Short Political Science Paper on Government Stability]. Parlamentní zpravodaj 2: 296-297.

Novák, M. 1996c. "Volby do poslanecké sněmovny, vládní nestabilita a perspektivy demokracie v České republice" [Elections into the Lower Chamber of Parliament, Government Instability, and Perpectives for Democracy in the Czech Republic]. Sociologický časopis 32: 407-422.

Novák, M. 1997. Systémy politických stran [Political Party Systems]. Praha: SLON.

Pehe, J. 1999. "Nový volební systém: Na koho je to past?" [The New Electoral System: A Pitfall for Whom?] Lidové noviny, May, 22: 10.

Popper, K. R. 1988. “The Open Society and its Enemies Revisited”. Pp. 25-28 in The Economist, April 23.

Quermonne, J.-L. 1991.“Alternance au pouvoir, multipartisme et pluralisme imparfait”. Pp. 77-88 in Idéologies, partis politiques et groupes sociaux: Etudes réunies pour Georges Lavau. Paris: Presses de la Fondation nationale des sciences politiques, coll. Référence (2nd edition, first edition 1989).

Quermonne, J.-L. 1995. L'alternance au pouvoir. Paris: Presses universitaires de France (2nd edition, first edition 1986).

Riker, W. H. 1962. The Theory of Political Coalitions. New Haven: Yale University Press.

Sartori, G. 1976. Parties and Party Systems: A Framework for Analysis. New York: Cambridge University Press.

Sartori, G. 1994. Comparative Constitutional Engineering. New York and London: Macmillan

Schofield, N. 1995. "Coalition Politics: A Formal Model and Empirical Analysis." Journal of Theoretical Politics 7: 245-281.

Schumpeter, J. A. 1962. Capitalism, Socialism and Democracy. New York: Harper and Row (3rd edition, first edition 1942).

Schwartzenberg, R. G. 1977. Sociologie politique. Paris: Montchrestien.

Strøm, K. 1990. Minority Governments and Majority Rule. Cambridge: Cambridge University Press.

Ware, A. 1996. Political Parties and Party Systems. Oxford: Oxford University Press. 